\title{
Separation and Characterization of the Active Soil- Aggregating Agent Present in Distillery Slops
}

\author{
Raúl Pérez Escolar ${ }^{1}$ \\ INTRODUCTION
}

Rum distillery slops are quite low in total solids. The fermentation process by which alcohol and carbon dioxide are produced or evolved is very exhaustive, and the resulting waste product has a brownish color and contains approximately 90 percent of water. In the process, practically all of the energy-producing materials are decomposed, and it is difficult to conceive the presence in the slops of any appreciable amount of material or materials capable of stabilizing the soil aggregates. Nevertheless, materials of this type are present. The author $(10,11,12,13)^{2}$ found rum distillery slops to have excellent soil-aggregating properties.

The purpose of this study was to determine the nature of the soil-aggregating agent or agents present in rum distillery slops.

\section{METHODS AND RESULTS}

The soil-aggregation property itself was used as the index to identify the fraction of the slops where the active agent was present.

The distillery slops were divided into two major portions, following the technique of Aronoff, Benson, Hassid, and Calvin (1). This technique involves the separation of the materials which are soluble from those insoluble in 80-percent ethyl alcohol. The former portion contains' sugars, organic acids, and amino acids. The latter contains proteins, polysaccharides, and insoluble salts.

The separate portions of the slops were tested for activity with unstable aggregates of $\mathrm{Fe}$ (Faith) clay, an alluvial heavy clay soil of southwestern Puerto Rico, high in exchangeable sodium and free salts. A description of the methods used and the results obtained are given in table 1 . The decrease in aggregate stability from 66.8 to 44.0 percent represents a loss of about $1 / 3$ of the activity of the alcohol-insoluble fraction, whereas with the alcohol-soluble fraction the decrease amounts to $5 / 6$ of the original activity.

The 80-percent alcohol-insoluble material was refluxed with petroleum ether for 24 hours in a Soxhlet appartus. After the petroleum ether was evaporated, only a small amount of residue was found. This material

${ }^{1}$ Associate Soil Scientist, Agricultural Experiment Station, Mayagüez Campus, University of Puerto Rico, Río Piedras, P.R.

${ }^{2}$ Italic numbers in parentheses refer to Literature Cited, pp. 307-8. 
was suspended in $10 \mathrm{ml}$. of water and added to soil aggregates by the previously described method. This fraction did not stabilize soil aggregates above the value recorded for the control.

The next step was to determine the nature of the 80 -percent alcohol-insoluble fractions. The possible presence of polysaccharides and of proteinaceous materials was suspected.

Following the technique of Chung and Nickerson (4) for the study of polysaccharides in yeasts, the active fraction was divided into 3 parts, namely: 1, The water-soluble; 2, 10-percent trichloroacetic-acid-soluble; and 3 , the fraction insoluble in the former two solvents. Tests indicated that the water-soluble portion of the fraction comprised 87 percent of the

\section{TABLE 1.-Differential stability of 2-3- $\mathrm{mm}$. Fe $\mathrm{e}^{1}$-clay aggregates when submitted to indicated treatments}

\begin{tabular}{l|c|c}
\hline \multicolumn{1}{c|}{ Method of measuring aggregate stability } & \multicolumn{2}{c}{$\begin{array}{c}\text { Degree of stability } \\
\text { (percent) } \\
\text { when- }\end{array}$} \\
\cline { 2 - 3 } & Treated & Untreated \\
\hline $\begin{array}{l}\text { Slops, } 10 \mathrm{ml} \text {., 80-percent alcohol-soluble fraction and allowed } \\
\text { to stand } 3 \mathrm{hr} \text {. prior to wet screening }\end{array}$ & 31.7 & $<1.0$ \\
$\begin{array}{l}\text { Bryant, Bendixon, and Slater (24 hr. after application of } \\
\text { slops), soluble fraction }\end{array}$ & 5.0 & $<1.0$ \\
$\begin{array}{l}\text { Slops, 80-percent alcohol-insoluble fraction, allowed to stand } \\
3 \mathrm{hr} \text { prior to wet screening }\end{array}$ & 66.8 & $<1.0$ \\
$\begin{array}{c}\text { Bryant, Bendixon and Slater (24 hr. after application of } \\
\text { slops), insoluble fraction }\end{array}$ & 44.0 & $<1.0$ \\
\hline
\end{tabular}

${ }^{1} \mathrm{Fe}$ is Spanish for "Faith," hence this is not a clay rich in iron.

active residue, the trichloroacetic-acid soluble portion, 6 percent, and the remainder, insoluble in both water and trichloroacetic acid, 7 percent.

The trichloroacetic-acid-soluble fraction was tested for phosphates, using the ammonium molybdate method. Negative results were obtained, indicating the absence of phosphorylated sugars.

The anthrone test for carbohydrates (16) was positive. To this fraction an excess of barium acetate was added, and the $\mathrm{pH}$ was brought to 8.2 with $\mathrm{KOH}$. The sample was then chilled, and a precipitate formed. The sample was then centrifuged and the barium acetate-soluble and -insoluble fractions were separated. Several tests were conducted on these fractions.

Both the barium acetate-soluble and -insoluble fractions yielded a positive anthrone test, but were negative to the resorcinol test for ketoses (14). The trichloroacetic-acid-soluble fraction, as well as the barium acetatesoluble and insoluble fractions were examined for carbohydrates using the carbazole test. All three fractions yielded a brown color which is 
indicative of the presence of mannose. The barium acetate-insoluble fraction was subjected to acid hydrolysis using $6 \mathrm{~N} \mathrm{HCl}$. This fraction, however, resisted acid hydrolysis. A further test using the Bechman, D. U. Spectrophotometer failed to show the presence of galactose, glucose, or mannose.

The water-soluble and the 10-percent trichloroacetic-acid-insoluble fractions which were soluble in $\mathrm{KOH}$, gave negative tests by the anthrone reaction for carbohydrates. These fractions were extremely resistant to acid hydrolysis. When the fraction soluble in $\mathrm{KOH}$ was dissolved in $1 N \mathrm{KOH}$, and the $\mathrm{K}$ precipitated as $\mathrm{KCLO}_{4}$, a positive test was obtained for the presence of $\mathrm{NH}_{2}$ groups using ninhydrin reagent (9), indicating the presence of proteins.

Several additional tests were made on the water-soluble fraction of the slops active residue. Acid hydrolysis using $6 \mathrm{~N} \mathrm{HCl}$ was not feasible, since the material flocculated as soon as the sealed ampule was put in a hot water bath. The fraction that seemed to hydrolize, or which at least seemed to become soluble, was dried in a vacuum oven. Attempts were made to dissolve it, but without success. This behavior seemed to indicate that this material was not a polysaccharide.

Paper electrophoresis was next used in an attempt to try to separate the water-soluble fraction. A closed-strip electrophoresis apparatus was employed using 2-molar acetic acid as the buffer solution. A potential of 143 v. was applied to the electrodes. Two strips were used. One of them was left for 3 hours and the other for 24 .

After separation was believed to have been achieved, a test for glucoproteins was conducted according to the technique of Drevon, and Konikan (6). Negative results were obtained. Tests for amino sugars following the method of Rydon (15) were also conducted, but negative results were obtained.

Tests for phenols using the Folin-Ciocalteu reaction ( $(7)$ were very weak. When the spectrum was run in the ultraviolet region, no indication of the presence of phenols appeared. (Phenols give maximum absorption in the region of $280 \mathrm{~m} \mu$.) It was believed that this fraction might be caramelized sugar. A caramel was prepared from sucrose in the laboratory by partial combustion. The caramel was extracted with water and $1 \mathrm{ml}$. of solution was added to $1 \mathrm{ml}$. of $2 \mathrm{~N} \mathrm{HCl}$. The solution was sealed in an ampule and acid hydrolysis was attempted. It was observed that the caramel flocculated as did the unknown fraction isolated from the slops. Two different tests for caramels were conducted on the water-soluble fraction of the slops active residue. One of these was the method of Lichthardt (8), which uses tannic and sulfuric acids in solution. In the test, a precipitate is formed which dissolves in hot water. Upon standing for 12 hours, a very 
heavy brown precipitate characteristic of caramels was formed with the unknown. Another qualitative test for caramel is that of Wood-NewHall (17). In this test phenylhydrazine-hydrochloride and sodium acetate, the reagents involved, yielded a brown precipitate, corroborating the presence of a caramel. A personal communication from Dr. Wendell W. Binkley (2) (Director Sugar Research Foundation) indicated that the presence of nitrogen, determined by the microdiffusion technique (5), is characteristic of the presence of mealanoidins, a product resulting from the condensation of sugars and proteins or sugar and amino acids. Since only 0.31 -percent N was found in the slops active residue, (water-soluble fraction), it must be present in only small amounts.

\section{SUMMARY}

Information resulting from laboratory studies is presented to show the nature of the soil-aggregating and stabilizing agents present in rum distillery slops. It was found that the main agents were constituents of the 80-percent alcohol-insoluble fraction of the rum distillery slops as shown by determining its soil-aggregate-stability activity. Fractionation of the active material indicated that 6 percent of it was a mannose-bearing polysaccharide, 7 percent protein, and the rest, 87 percent, or main constituent, was a caramel. This one results from the sucrose recovery process at the sugar factory and is not attacked by yeast in the molasses fermentation process.

\section{RESUMEN}

Se presenta la información obtenida de los estudios de laboratorio que se llevaron a cabo para demostrar la naturaleza de los materiales presentes en el mosto de las destilerías, capaces de agregar y estabilizar los conglomerados del suelo. Se determinó que los principales agentes se encuentran en la fracción insoluble en alcohol al 80 por ciento, como lo demostó la prueba de estabilidad de los agregados del suelo. El material activo separado demostró consistir de un 6 por ciento de un polisacárido de manosa, un 7 por ciento de proteína y un 87 por ciento de un caramelo. Esta última substancia es el producto del proceso de la recuperación del aźucar en la fábrica y no la afectan las levaduras en el proceso de fermentación de las mieles.

\section{LITERATURE CITED}

1. Aronoff, S. A., Benson, W. Z., Hassid, W. Z., and Cavin, M., Science 105: 664, 1943.

2. Binkley, Wendell, W., personal communication.

3. Bryant, J. C., Bendixen, T. W., and Slater, C. S., Measurements of the water stability of soils, Soil Sci. 65: 341-5, 1948. 
4. Chung, C. W., and Nicerson, Walter, J., Polysaccharide synthesis in growing yeasts, J. Biol. Chem. 208: 395-407, 1953.

5. Conway, Edward, J., Microdiffusion analysis and volumetric error, 3d ed., pp. 1-13, 1950.

6. Drevon, B., and Donidan, R., Soc. Chem. Biol. B. 37: 1321-5, 1955.

7. Folin, O., and Ciocalteu, V., On tyrosine and tryptophane determinations in proteins, J. Biol. Chem. 73: p. 627, 1927.

8. Lichthardt, G. H. P., Identification test for caramel, Ind. Eng. Chem. 2: 389, 1910.

9. Moore, S., and Stein, W. H., Photometric ninhydrin method for use in the chromatography of amino-acids, J. Biol. Chem. 76: 367, 1948.

10. Pérez Escolar, R., Stability of Soil Aggregates treated with distillery slops or blackstrap molasses, J. Agr. Univ. P. R. 50(3): 174-85, 1966.

11. - Reclamation of a saline sodic soil by use of molasses and distillery slops, J. Agr. Univ. P. R. 50(3): 209-17, 1966.

12. - Characterization of clays and clay-organic complexes, J. Agr. Univ. P. R. $50(4)$ : 303-15, 1966.

13. - - Use of molasses and distillery slops in conjunction with sulfur for the reclamation of a saline sodic and a sodic soil from P. R., J. Agr. Univ. P. R., 51 (1): 55-65, 1967.

14. Roe, Joseph H, A colorimetric method for the determination of fructose in blood and urine, J. Biol. Chem. 107: 15-22, 1934.

15. Rydon, H. N., and Smith, P. W. G., A new method for the detection of peptides and similar compounds on paper chromatograms, Nature, London 169: 922, 1952.

16. Sattler, L., and Zerban, F. W., The Dreywood Anthrone Reaction as affected by carbohydrate structure, Science 108: 207, 1948.

17. Woodman, A. G., and Newhall, E. H., A modification of Anthor Test for caramel, Mass. Inst. Tech. Quart. 21: 280, 1908. 